5. Ignatov, P.E. (1995). Ocherki ob infektsionnyih boleznyah u sobak [Sketch book on infectious diseases in dogs]. M.: Valta [in Russian].

6. Lyarski, Z. (1980). Diagnostika virusnyih bolezney zhivotnyih [Diagnosis of viral diseases in animals]. V.N. Syurina (Ed.). M.: Kolos [in Russian].

7. Maksimovich, V.V. et al. (2010). Chastnaja jepizootologija [Specialty Epizootology]. Minsk [in Russian].

8. Abramov, S.S. (2013). Veterinarnaya entsiklopediya [Veterinary Encyclopaedia]. A.I. Yatusevicha (Ed.). (Vols. 1-6). V.2. Minsk [in Russian].

\title{
УДК. 619:615.371:616.988.5:631.1
}

КРИВОШИЯ П.Ю., канд. вет. наук, ст. наук. сп., е-mail: p.kryvoshyya@gmail.com

КОT Л.Б., e-mail: ksvlvm@ukr.net, POМАНКО M.B., e-mail: maximromanko@gmail.com Дослідна станизія епізоотології Інституту ветеринарної медицини НААН РУДЬ О.Г., канд. вет. наук, доц., e-mail: oleg.rud-rud1965@ukr.net Рівненський державний гуманітарний університет

\section{ФАГОЦИТОЗ ТА РОЗЕТКОУТВОРЮВАЛЬНА АКТИВНІСТЬ НЕЙТРОФІЛІВ КРОВІ ЗА ПРИХОВАНОГО ПЕРЕБІГУ ІНФЕКЦІЙНОӤ АНЕМІї КОНЕЙ}

В статті наведено експериментальні дослідження по стану неспецифічного клітинного імунітету при інфекційній анемії коней. Встановлено пригнічення функціональної активності при фагоцитозі нейтрофілів у хворих коней. Наведені результати розеткоутворюючої здатності нейтрофілів крові коней до маркерів $T$ - $i$ Bлімфоцитів, фагоцитарної активності за прихованого перебігу інфекиійної анемії (IНАН). Встановлено зменшення експресї рецепторів нейтрофілів до маркерів Т-лімфоцитів $у$ хворих коней $(p<0,01)$ та збільшення ї̈ до маркерів В-лімфочитів $(p<0,05)$, зниження фагоцитозу нейтрофілів крові, щу характеризувалось зниженням фагоцитарної активності та фагоиитарного числа $(p<0,01)$. фагоичтоз.

Ключові слова: коні, інфекиійна анемія, нейтрофіли, маркери $T$ - $i$ В-лімфоцитів,

Вступ. Постійне збільшення племінних конеферм та розвиток кінного туризму в нашій країні за останні роки спонукає до розв'язання питань про благополуччя даної галузі щодо інфекційних захворювань.

Однією з важливих проблем у конярстві є інфекційна анемія коней, яка постійно реєструється в багатьох країнах 3 розвинутим конярством: США, Китаї, Бразилії, ряді держав південно-східної Азії та інших країнах. В Україні хвороба найбільш поширена в західному регіоні. Збудник - ретровірус, морфологічно подібний до ретровірусів лейкозу великої рогатої худоби, СНІДу та Т- клітинного лейкозу людини $[1,2]$.

Основні механізми розвитку патологічного процесу в організмі хворих тварин зумовлені імунологічними порушеннями, це підтверджують роботи 
багатьох учених [3-8].

Деякі автори вказують на пригнічення вірусом інфекційної анемії імунної системи та морфологічну спорідненість патогенезу хвороби зі СНІДом людини та онкорнавірусами [2].

Дослідження багатьох учених свідчать про те, що порушуються регуляторні механізми у хворих на IHАН тварин, крім цього, у них спостерігаються зниження числа Т-лімфоцитів, зниження проліферативної відповіді на неспецифічні мітогени, підвищення кількості В-лімфоцитів [6, 7].

У літературних джерелах $є$ незначна кількість повідомлень щодо імунологічних досліджень при інфекційній анемії коней та ряду важливих аспектів цієї проблеми, що стосуються зокрема вивчення стану імунітету, особливо при хронічному та латентному перебігу хвороби.

На сьогодні $є$ загальноприйнятою думка про те, що вірусна інфекція супроводжується появою нових антигенних варіантів, які змінюють рецепторний апарат клітини, що, в свою чергу, впливає на імунорегуляторні процеси в усьому організмі. Вивчення змін на поверхні клітин і оцінка їх ролі в розвитку інфекційного процесу має важливе значення для розкодування механізмів імуногенезу при інфекційній анемії.

Загальновідомо, що кількість таких імунокомпетентних клітин, як Тлімфоцити, визначають у тварин та людей за допомогою реакції спонтанного розеткоутворення, яка базується на здатності Т-клітин, завдяки наявності на їх поверхні відповідних рецепторів, адсорбувати еритроцити барана з утворенням розеток, а В-лімфоцитів по адсорбції еритроцитів барана, навантажених $\mathrm{C}_{3}$ компонентом комплементу. В ході проведення імунологічних досліджень у коней нами неодноразово було помічено, що адсорбувати маркерні еритроцити здатні не тільки лімфоцити, які є імунокомпетентними клітинами, але, зокрема, і нейтрофіли, що підтверджує наявність на поверхні даних клітин рецепторів, які аналогічні тим, що знаходяться на лімфоцитах.

Дані спостереження спонукали нас до більш глибокого вивчення рецепторного апарату даних клітин.

Мета роботи полягала у визначенні фагоцитарної та розеткоутворювальної активності нейтрофілів до маркерів Т- і В-лімфоцитів у здорових та хворих на інфекційну анемію коней у динаміці розвитку інфекційного процесу.

Матеріали і методи досліджень: Розеткоутворювальну здатність та фагоцитарну активність нейтрофілів крові коней визначали, користуючись методичними рекомендаціями Бусола В.О. та ін. [9].

3 урахуванням віку тварин, сезону року, умов утримання і результатів серологічних досліджень в реакції дифузної преципітації (РДП) на IНАН 43 голови коней розділили на три групи щодо вмісту титру антитіл у сироватці крові тварин. У першу групу увійшли 19 тварин, в сироватці крові яких були відсутні антитіла до вірусу ІНАН. У другу увійшли 20 коней з титром антитіл до вірусу анемії коней в РДП 1:2 - 1:8. У третю - 4 тварини 3 титром 1:16 - 
1:32. Все поголів'я було у віці від 10 до 12 років і утримувалось в однакових умовах. Дослідження проводили в осінній сезон.

Стан експресії рецепторів клітин крові коней визначали шляхом оцінки їх здатності приєднувати визначену кількість індикаторних еритроцитів. За цією ознакою кожну популяцію клітин розділили на чотири групи. У першу групу увійшли клітини крові, які приєднали три еритроцити, у другу - чотири, в третю - від п’яти до дев’яти і в четверту - від десяти і більше. Для більш об’єктивної оцінки показників проводили підрахунок 200 клітин крові.

Результати досліджень та їх обговорення. Дані результатів досліджень стану експресії рецепторів нейтрофілів крові до маркерів Т-лімфоцитів згаданих вище груп тварин наведені в таблиці 1 та показано на рисунку 1.

Таблиця 1

Спонтанна розеткоутворювальна активність нейтрофілів до маркерів

T-лімфоцитів у здорових та хворих коней

\begin{tabular}{|c|c|c|c|c|c|c|c|}
\hline \multirow[b]{2}{*}{ Групи, } & \multirow[b]{2}{*}{$\begin{array}{c}\text { Титр } \\
\text { антитіл } \\
\text { в РДП }\end{array}$} & \multirow[b]{2}{*}{$\begin{array}{c}\text { Клітини } \\
\text { крові }\end{array}$} & \multicolumn{5}{|c|}{ Відсоток нейтрофілів, які приєднали: } \\
\hline & & & $\begin{array}{c}3 \\
\text { еритроцит } \\
\text { и } \\
\end{array}$ & $\begin{array}{c}4 \\
\text { еритроцит } \\
\text { и } \\
\end{array}$ & $\begin{array}{c}5-9 \\
\text { еритроциті } \\
\text { в } \\
\end{array}$ & \begin{tabular}{|c|}
10 і більше \\
еритроциті \\
в
\end{tabular} & $\begin{array}{c}\text { Сумарни } \\
\text { й вміст } \\
\text { клітин }\end{array}$ \\
\hline $\begin{array}{c}1- \\
\text { здорові }\end{array}$ & - & \multirow{6}{*}{$\begin{array}{c}\text { нейтрофі- } \\
\text { ли }\end{array}$} & $15,61 \pm 1,31$ & $4,40 \pm 1,07$ & $2,3 \pm 0,26$ & 0 & $22,3 \pm 2,57$ \\
\hline \multicolumn{2}{|c|}{$\%$} & & \multicolumn{2}{|c|}{89,7} & \multicolumn{2}{|c|}{10,3} & 100 \\
\hline 2-хворі & $1: 2-1: 8$ & & \multicolumn{2}{|c|}{\begin{tabular}{|l|l|l}
$155+151$ & $425+067$
\end{tabular}} & \multicolumn{2}{|c|}{$125+032$} & $21,0 \pm 3,87$ \\
\hline \multicolumn{2}{|c|}{$\%$} & & \multicolumn{2}{|c|}{94,0} & \multicolumn{2}{|c|}{6,0} & 100 \\
\hline 3-хворі & $\begin{array}{c}1: 16- \\
1: 32 \\
\end{array}$ & & $14,3 \pm 2,31$ & $3,67 \pm 0,19$ & $\begin{array}{c}0,67 \pm 0,12 * * \\
*\end{array}$ & 0 & $18,6 \pm 2,34$ \\
\hline \multicolumn{2}{|c|}{$\%$} & & \multicolumn{2}{|c|}{96,41} & \multicolumn{2}{|c|}{3,59} & 100 \\
\hline
\end{tabular}

Примітка: ступінь вірогідності $* * * \mathrm{p}<0,01$ встановлена у здорових коней та у хворих 3 титром антитіл до вірусу ІНАН в межах 1:2-1:32.

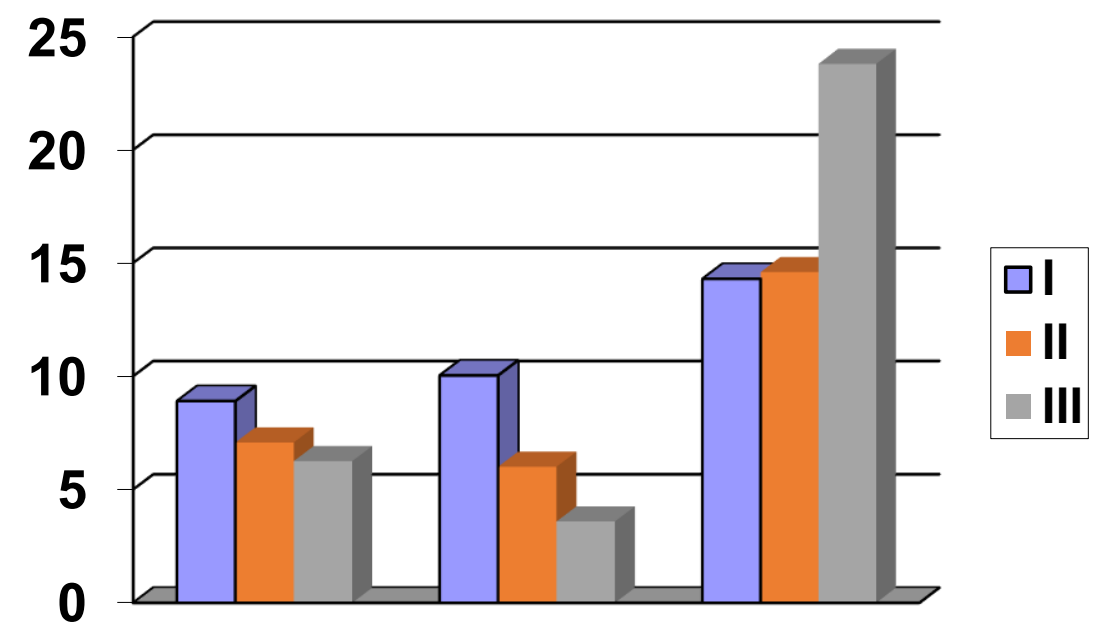

Рис. 1. Активність експресії повних розеток нейтрофілів крові у здорових та хворих на ІНАН коней залежно від титру антитіл до маркерів Т-лімфоцитів. 
3 даної таблиці видно, що у здорових тварин із загального вмісту клітин, в середньому $89,7 \%$ нейтрофілів утворюють неповні розетки, приєднуючи 3-4 еритроцити, і 10,3\% утворюють повні розетки за рахунок приєднання 5 і більше еритроцитів до маркерів Т-лімфоцитів. За прихованого перебігу інфекції в результаті взаємодії імунної системи організму з вірусом цей показник зазнає змін. Так, порівнюючи групи хворих коней з титром антитіл 1:2-1:8 та 1:16$1: 32$ із здоровими, встановлено вірогідну різницю $(\mathrm{p}<0,01)$ у зменшенні експресії рецепторів повних розеток на нейтрофілах у коней за прихованого перебігу інфекційної анемії. Порівнюючи дослідні групи хворих коней з різним титром антитіл в РДП тесті, виявлені більш суттєві зміни в групі тварин 3 високим титром антитіл. Отримані дані свідчать, що прихований перебіг інфекції супроводжується зменшенням експресії рецепторів на нейтрофілах до маркерів Т-лімфоцитів, що, можливо, пов'язане з блокуванням поверхні даних клітин комплексом вірус-антитіло. Стан експресії рецепторів нейтрофілів крові до маркерів В-лімфоцитів $\mathrm{C}_{3}$-компоненту - комплементу в досліджуваних групах тварин наведено в таблиці 2 та показано на рис. 2.

3 наведених результатів досліджень бачимо, що у здорових тварин із загального вмісту клітин, що утворювали розетки 3 трьома еритроцитами $\mathrm{i}$ більше, в середньому 94,76\% нейтрофілів утворюють неповні розетки, приєднуючи 3-4 еритроцити, і 5,24\% утворюють повні розетки за рахунок приєднання 5 і більше еритроцитів до маркерів В-лімфоцитів.

За прихованого перебігу IНАН у хворих коней з титром антитіл 1:16-1:32 порівняно зі здоровими тваринами встановлено вірогідну різницю $(\mathrm{p}<0,05)$ у збільшенні експресії рецепторів до маркерів В-лімфоцитів, які утворювали повні розетки на нейтрофілах.

Підсумовуючи проведений аналіз розеткоутворювальної активності нейтрофілів крові при ІНАН коней, нами встановлено, що рівень їх динамічно змінюється 3 розвитком інфекційного процесу, і зміни на рецепторах даних клітин є більш суттєвими при загостренні інфекційного процесу.

Таблиия 2

Спонтанна розеткоутворювальна активність нейтрофілів до маркерів Влімфоцитів у здорових та хворих коней

\begin{tabular}{|c|c|c|c|c|c|c|c|}
\hline \multirow[b]{2}{*}{$\begin{array}{c}\text { Групи, } \\
\%\end{array}$} & \multirow[b]{2}{*}{$\begin{array}{c}\text { Титр } \\
\text { антитіл } \\
\text { в РДП }\end{array}$} & \multirow[b]{2}{*}{$\begin{array}{l}\text { Клітини } \\
\text { крові }\end{array}$} & \multicolumn{5}{|c|}{ Відсоток нейтрофілів, які присднали } \\
\hline & & & $\begin{array}{c}\mathbf{3} \\
\text { еритроцити }\end{array}$ & $\begin{array}{c}4 \\
\text { еритроцити }\end{array}$ & $\begin{array}{c}5-9 \\
\text { еритроцитів }\end{array}$ & $\begin{array}{r}10 \text { і більше } \\
\text { еритроцитів }\end{array}$ & $\begin{array}{c}\text { Сумарний } \\
\text { вміст } \\
\text { клітин }\end{array}$ \\
\hline $\begin{array}{c}1- \\
\text { здорові }\end{array}$ & & \multirow{6}{*}{ 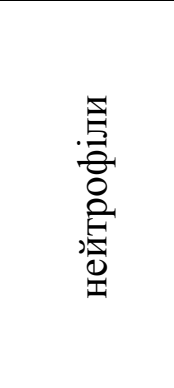 } & $5,8 \pm 07$ & $1,8 \pm 04$ & $0,42 \pm 0,09$ & 0 & $8,02 \pm 1,38$ \\
\hline \multicolumn{2}{|c|}{$\%$} & & \multicolumn{2}{|c|}{94,76} & \multicolumn{2}{|c|}{5,24} & 100 \\
\hline 2-хворі & $1: 2-1: 8$ & & \multirow{2}{*}{\multicolumn{2}{|c|}{\begin{tabular}{c|c}
$8,0 \pm 0,15$ & $0,9 \pm 0,18$ \\
95,10
\end{tabular}}} & $0,51 \pm 0,14$ & 0 & $10,4 \pm 2,07$ \\
\hline \multicolumn{2}{|c|}{$\%$} & & & & \multicolumn{2}{|c|}{4,90} & 100 \\
\hline 3-хворі & $\begin{array}{r}1: 16- \\
1: 32\end{array}$ & & $10,5 \pm 3,11$ & $4,0 \pm 0,32$ & $1,75 \pm 0,51 * *$ & 0 & $16,25 \pm 3,0$ \\
\hline \multicolumn{2}{|r|}{$\%$} & & \multicolumn{2}{|c|}{89,23} & \multicolumn{2}{|c|}{10,77} & 100 \\
\hline
\end{tabular}

Примітка: ступінь вірогідності ** $<<0,05$, встановлена у здорових коней та у хворих 3 титром антитіл до вірусу ІНАН в межах 1:2-1:32. 


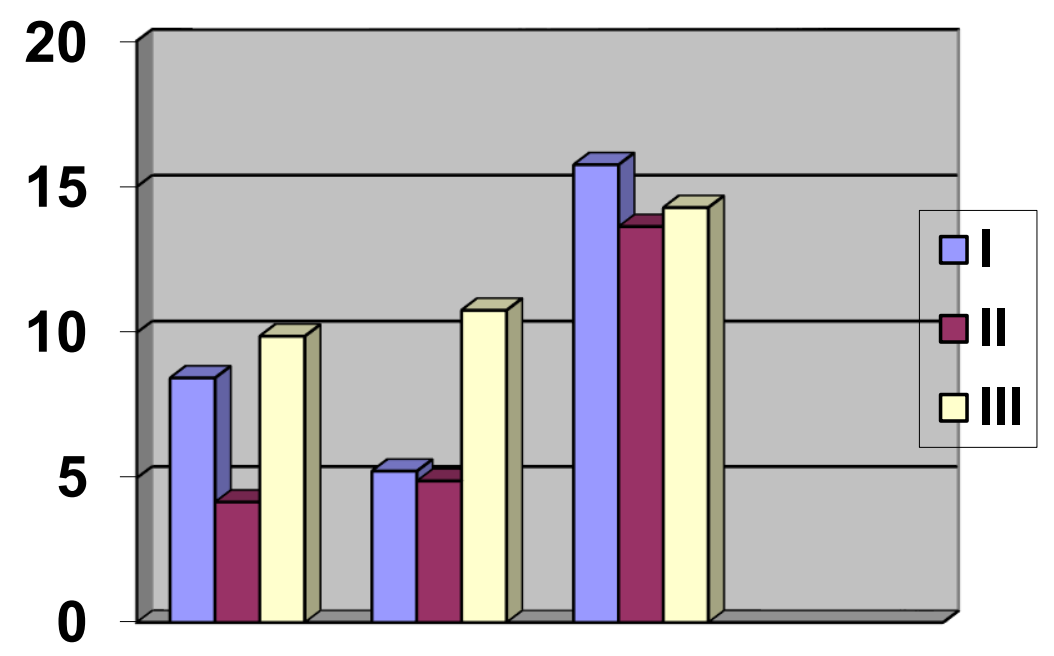

\section{Рис. 2. Активність експресії повних розеток нейтрофілів крові у здорових та хворих на ІНАН коней залежно від титру антитіл до маркерів В-лімфоцитів.}

При оцінці фагоцитарного ланцюга імунітету (табл. 3) було встановлено, що перебіг хвороби приводить до зниження фагоцитарної активності (ФА). Так, ФА у здорових коней через 5 годин інкубації після взяття проб крові для

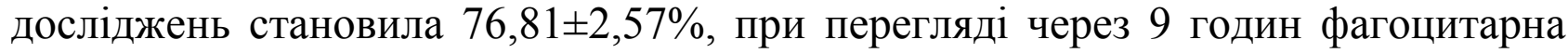
активність підвищилась і була $80,43 \pm 5,43 \%$, що на $3,62 \%$ вища і вказує на включення у фагоцитоз інтактних нейтрофілів, через 13 годин ФА була знижена і становила $76,81 \pm 3,27 \%$, що вказує не на зниження ФА, а на лізис бактеріальних клітин певної частини нейтрофілів. Така подібна закономірність простежується i по фагоцитарному числу (ФЧ). На один фагоцитуючий нейтрофіл кількість бактерій St. albus при обліку через 5 годин становила $50,0 \pm 3,34$, через $9-121,2 \pm 7,8$, через $13-82,8 \pm 4,72$. Так на 9-у годину інкубації було встановлено не тільки підвищення фагоцитарної активності, але й загальну кількість захоплених бактерій, що вказує на те, що в даний період інкубації не тільки проходить активація інтактних нейтрофілів крові, але й підвищення загальної активності фагоцитуючих нейтрофілів, що підтверджується збільшенням загальної кількості захоплених бактерій. На 13-й годині інкубації вміст бактерій був знижений з $121,2 \pm 7,8$ до $82,8 \pm 4,72$, що вказує на лізис третини бактерій за досить короткий період часу. В свою чергу, в коней, інфікованих вірусом IHАН, фагоцитарна активність була знижена порівняно 3 контрольною групою і через 5 годин становила $56,0 \pm 4,34 \%$, що було на 20,8\% нижче від контрольної групи. Через 9 годин показник фагоцитозу досяг величини $76,8 \pm 4,51 \%$, і різниця 3 контрольною групою становила лише $3,6 \%$, через 13 годин інкубації рівень фагоцитуючих нейтрофілів був знижений лише на $1 \%$. За кількістю захоплених бактерій на один нейтрофіл (ФЧ) простежується низький їх рівень порівняно 3 контрольною групою. Так, захоплююча здатність нейтрофілів у хворих тварин через 5 годин інкубації була знижена в 3 рази $(\mathrm{p}<0,01)$, через 9 годин - у 1,5 рази $(\mathrm{p}<0,05), 13$ годин - у 2,5 рази $(\mathrm{p}<0,01)$ порівняно 3 контрольною 
групою. Підсумовуючи вище викладений матеріал, необхідно відмітити, що функціональна активність нейтрофілів знижена в інфікованих коней, що підтверджує факт низького рівня захоплених бактерій, хоча рівень лізису бактерій був вищий порівняно 3 контрольною групою. На нашу думку, це пов'язано з низьким вмістом бактерій на один нейтрофіл, що дає можливість використання більшої кількості ензимів, які будуть приймати участь у розщепленні одного мікроба. Встановлено, що фагоцитоз нейтрофілів крові коней, серологічно позитивних на інфекційну анемію, характеризується зменшенням рівня фагоцитарної активності та фагоцитарного числа.

Таблиия 3

Показники фагоцитозу в здорових та хворих на інфекційну анемію коней в динаміці проведених досліджень

\begin{tabular}{|c|c|c|c|c|c|c|c|}
\hline \multirow{2}{*}{$\begin{array}{c}\text { Дослідні } \\
\text { групи }\end{array}$} & \multirow{2}{*}{$\begin{array}{c}\text { Нейтрофіли, } \\
\text { \% }\end{array}$} & \multicolumn{4}{|c|}{ Фагоцитарна активність, \% } & \multicolumn{3}{|c|}{$\begin{array}{c}\text { Фагоцитарне число, } \\
\text { ум.од. }\end{array}$} \\
\cline { 3 - 8 } & & \multicolumn{3}{|c|}{ Період досліджень після взяття проб крові, години } \\
\cline { 3 - 8 } & $\mathbf{5}$ & $\mathbf{9}$ & $\mathbf{1 3}$ & $\mathbf{5}$ & $\mathbf{9}$ & $\mathbf{1 3}$ \\
\hline \multirow{2}{*}{ здорові } & $39,75 \pm 3,34$ & $76,81 \pm 2,57$ & $\begin{array}{c}80,43 \pm \\
5,43\end{array}$ & $76,81 \pm 3,27$ & $\begin{array}{c}50,0 \\
\pm 3,34\end{array}$ & $\begin{array}{c}121,2 \pm \\
7,8\end{array}$ & $\begin{array}{c}82,8 \pm \\
4,72\end{array}$ \\
\hline \multirow{2}{*}{ хворі } & $45,29 \pm 4,15$ & $56,0 \pm 4,34$ & $76,80 \pm 4,51$ & $75,83 \pm 3,11$ & $\begin{array}{c}17,44 \pm \\
2,71 * *\end{array}$ & $\begin{array}{c}82,58 \pm \\
6,13 *\end{array}$ & $\begin{array}{c}31,9 \\
\pm 2,59 * *\end{array}$ \\
\hline
\end{tabular}

Примітка: ступінь вірогідності: ** - $<<0,01, *$ - $<<0,05$ порівняно зі здоровими тваринами.

\section{Висновки та перспективи подальших досліджень.}

1. 3 розвитком інфекційного процесу за прихованого перебігу IHAH коней в неімунокомпетентних клітинах крові, зокрема нейтрофілах, встановлені вірогідні зміни експресії рецепторів до маркерів Т- і В- лімфоцитів.

2. Визначено, що розеткоутворювальна активність до маркерів Тлімфоцитів із загостренням інфекційного процесу була вірогідно зниженою, а до В- лімфоцитів - підвищеною.

3. Встановлено пригнічення фагоцитарної активності нейтрофілів, що підтверджується кількістю захоплених бактеріальних клітин та участю нейтрофілів у цьому процесі.

\section{СПИСОК ЛІТЕРАТУРИ}

1. Charles I. I. Prospective study of proqeny of inapparent equine carriers of equine infectious anaemia virus / I.I. Charles, W.V. Adams, D.F. Lane / Am. J. veter. Res. - 1988. - Vol. 17, №3. - P. 251-286.

2. Gerencer M. Qalitative analyses of cellular immune functions in equine infectious anaemia show homology with AIDS. / M. Gerencer, I.Valpotic, B. Juric // Areh. Virol. - 1989. Vol. 104. - № 3-4. - P. 495-504.

3. Макаров В.В. Иммунопатология при вирусных болезнях животных. / В.В. Макаров, С.Ф. Чевелев, А.А. Коломыцев // Ветеринария. - 1982. - №2. - С. 29-36.

4. Орлов Ф.М. Инфекционная анемия лошадей / Ф.М. Орлов // Инфекционные и инвазионные болезни лошадей М.: «Колос», - 1976, С. 61-75.

5. Осидзе Д.Ф. Инфекционные болезни животных. Справочник. / Д.Ф. Осидзе М.: ВО «Агропромиздат», 1987. - 288 с. 
6. Shively M. A. Antigenic stimulation of T-lymphocytes in chronic nononcogenic retrovirus infection: equine infectious anaemia. / M.A. Shively, R.L. Banks, A. Gerencer, P. Klevjer-Anderson // Infection and Immunity. - 1982. - Vol. 36. - P. 38-46.

7. Valpotic I. In vitro reactivity of lymphocytes in horses affected by equine infectious anaemia to mitogens and specific antigens / I. Valpotic, M. Gerencer, B. Juric / Periodicum. biologorum. - 1983. - Vol. 85 - N. 3 - P. 233-235.

8. Valpotic I. Histocytochemical demonstration of immunocompetent cells in horses with acute type equine infectious anaemia / I. Valpotic, B. Rode, B. Juric, I. Basic // Vet. arch. - 1986. Vol. 55. - N. 6. - P. 267-268.

9. Оцінка імунного статусу коней в нормі і за прихованого перебігу інфекційної анемії. Методичні рекомендації / В.О. Бусол, М.С. Мандигра, О.С. Галатюк та ін. - Інститут епізоотології. - Рівне, 1996. - 26 с.

\section{ФАГОЦИТОЗ И РОЗЕТКООБРАЗУЮЩАЯ АКТИВНОСТЬ НЕЙТРОФИЛОВ КРОВИ ПРИ СКРЫТОМ ТЕЧЕНИИ ИНФЕКЦИОННОЙ АНЕМИИ ЛОШАДЕЙ / Кривошея П.Ю., Кот Л.Б., Романко М.В., Рудь О.Г.}

В статье приведены экспериментальные исследования состояния неспецифического клеточного иммунитета при инфекционной анемии ломадей. Установлено угнетение функииональной активности при фагоцитозе нейтрофилов у больных лошадей. Приведеньл результаты розеткообразующей способности нейтрофилов крови лошадей к маркерам Т- $u$ B-лимфоциттов, фагоџитарной активности при скрытом течении инфекционной анемии (ИНАН). Установлено уменьшение экспрессии рецепторов нейтрофилов $\kappa$ маркерам Tлимфоцитов у больных лошадей $(p<0,01)$ и увеличение её к маркерам В-лимфоцитов $(p<0,05)$, снижение фагоцитарной активности нейтрофилов крови и фагоцитарного числа $(p<0,01)$.

Ключевые слова: лошади, инфекиионная анемия, нейтрофиль, маркеры $T$ - $и$ Bлимфоцитов, фагоччитоз.

PHAGOCYTOSIS AND SOCKETS FORMING ACTIVITY OF NEUTROPHILS IN THE LATENT COURSE OF EQUINE INFECTIOUS ANAEMIA / Kryvoshyja P.Ju., Kot L.B., Romanko M.V., Rud' O.G.

Introduction. One of the important problems in horse breeding is infectious anemia, which is constantly registered in many countries. Pathogen is a retrovirus, morphologically similar to bovine leukemia virus. disorders.

Basic mechanisms of pathological process in organism were caused by immunological

Researches indicate about violation of regulatory mechanisms, decrease in the number of $T$ lymphocytes, decrease of non-specific proliferative response to mitogens, increase of the $B$ lymphocytes number.

These observations led us to a deeper study of cells receptor system.

The goal of the work was to identify rosetting and phagocytic activities of neutrophils in healthy and sick with infectious anemia horses in the dynamics of infection.

Materials and methods: research of rosette forming phagocytic activities of horses neutrophils were determined using the guidelines of Busol V.A. etc.

43 horses of 10-12 years old were divided into three groups by the titer of antibodies to the EIA (Equine Infectious Anaemia) virus in the animal's serum (19-without antibodies, 20 - 1:21:8, 4 -1:16-1:32). All horses were kept under the same conditions. The study was conducted in the fall season. 
Results of research and discussion. In healthy animals $89.7 \%$ neutrophils formed incomplete rosettes, with 3-4 erythrocytes, and 10.3\% formed complete rosettes attaching 5 or more red blood cells. Comparing the group of sick animals (1:2-1:8, 1:16-1:32) with healthy, we found significant difference $(p<0.01)$ in reducing the expression of full rosette receptors on the neutrophils.

We have found significant difference $(p<0.05)$ of increased expression of receptors for $B$ lymphocytes markers, which formed complete rosettes on neutrophils in sick horses with latent stage of EIA (1:16-1:32) compared with healthy animals. We also found that the level of rosette forming activity of neutrophils changed dynamically with the development of infection and changes in the receptors of these cells is more significant in the exacerbation of infection.

\section{Conclusions and prospects for further research:}

1. With the development of latent EIA infection changes of receptors expression to $T$ - and $B$ lymphocytes markers are detected in neutrophils.

2. Determined that the rosette forming activity for T-lymphocytes markers with exacerbation of infection was reduced and increased to the B-lymphocytes.

3. Established inhibition of phagocytic activity of neutrophils, that confirmed by the number of captured bacterial cells and neutrophils participation in the process.

Keywords: infectious anemia, horses, neutrophils, markers of $T$ - and B-lymphocytes, phagocytosis.

\section{REFERENCES}

1. Charles, I.I., Adams, W.V. \& Lane, D.F. (1988). Prospective study of progeny of inapparent equine carriers of equine infectious anaemia virus. Am. J. veter. Res, 17, 3, 251-286.

2. Gerencer, M., Valpotie, I. \& Juric, B. (1989). Qalitative analyses of cellular immune functions in equine infectious anaemia show homolody with AIDS. Arch. Virol., 104, 3-4, 495-504.

3. Makarov, V.V., Chevelev, S.F. \& Kolomycev, A.A. (1982). Immunopatologija pri virusnyh boleznjah zhivotnyh [Immunopathology at viral diseases of animals]. Moscow: Veterinarija [in Russian].

4. Orlov, F.M. (1976). Infekcionnaja anemija loshadej [Equine infectious anemia]. Infekcionnye i invazionnye bolezni loshadej - Infectious and parasitic diseases of horses. Moscow: Kolos [in Russian].

5. Osidze, D.F. (1987). Infekcionnye bolezni zhivotnyh [Infectious animal diseases]. Moscow: Agropromizdat [in Russian].

6. Shively, M.A., Banks, R.L., Gereenlee, A. \& Klevjer-Anderson, P. (1982). Antigenic stimulation of T-lymphocytes in chronic nononcogenic retrovirus infection: equine infectious anaemia. Infection and Immunity, 36, 38-46.

7. Valpotic, I., Gerencer, M. \& Juric, B. (1983). In vitro reactivity of lymphocytes in horses affected by equine infectious anaemia to mitogens and specific antigens. Periodicum. biologorum, $85,3,233-235$.

8. Valpotic, I., Rode, B. \& Juric, B. (1986). Histocytochemical demonstration of immunocompetent cells in horses with acute type equine infectious anaemia. Vet. arch., 55, 6, 267268.

9. Busol, V.O., Mandygra, M.S. \& Galatjuk, O.J. (1996). Ocinka imunnogo statusu konej v normi i za pryhovanogo perebigu infekcijnoi' anemii' [Evaluation of the immune status of horses in the norm and in latent stage of infectious anemia]. Rivne: Instytut epizootologii [in Ukrainian]. 